\title{
Implementasi Model Inkuiri dalam Pembelajaran Pendidikan Agama Islam dan Budi Pekerti: Analisis pada Materi Pembelajaran Toleransi
}

\author{
Kiki Ayu Hermawati \\ Institut Agama Islam Negeri Ponorogo, Indonesia \\ Jl. Pramuka No. 156 Ronowijayan, Kota Ponorogo, Jawa Timur \\ Email: khikiyayu@gmail.com
}

\begin{abstract}
This paper aims to analyze the application of the inquiry learning model to the subject of Islamic Religious Education and character education on the subject of tolerance. Using qualitative research methods with a case study approach and data collected by in-depth interviews with Islamic Religious Education teachers and Headmasters. Data is processed and analyzed by data reduction, presenting data and drawing conclusions. The results of this study are; application of inquiry learning models in tolerance material by providing opportunities for students to ask questions related to intolerant cases in the form of terrorism; forming small groups for 4-5 students, directing them to discuss and draw a conclusion from the problem of tolerance material by linking the basis of God's word in the Qur'an. In addition, it develops learning in the form of observing the material being studied with the development of society. The results of this study have implications for the development of "inquiry learning model theory in tolerance learning" in Islamic religious education learning.
\end{abstract}

Keywords: Inquiry Learning Model, Islamic Religious Education, Educators, Students, Tolerance.

Abstrak: Tulisan ini bertujuan untuk menganalisis penerapan model pembelajaran inkuiri pada mata pelajaran Pendidikan Agama Islam dan Budi Pekerti pada materi toleransi. Menggunakan metode penelitian kualitatif dengan pendekatan studi kasus serta data dikumpulkan dengan wawancara mendalam pada guru Pendidikan Agama Islam dan Budi Pekerti dan Kepala sekolah. Data diolah dan dianalisis dengan reduksi data, menyajikan data dan menarik kesimpulan. Hasil penelitian ini adalah; penerapan model pembelajaran inkuiri dalam materi toleransi dengan memberikan kesempatan pada peserta didik pertanyaan terkait kasus intoleran berupa terorisme; membentuk kelompok kecil untuk peserta didik 4-5 orang, mengarahkan mereka melakukan diskusi dan menarik sebuah kesimpulan dari masalah materi toleransi dengan mengaitkan dasar firman Allah dalam al-Qur'an. Di samping itu mengembangkan pembelajaran berupa pengamatan materi yang dipelajari dengan perkembangan masyarakat. Hasil penelitian ini berimplikasi pada pengembangan "teori model pembelajaran inkuiri dalam pembelajaran toleransi" dalam pembelajaran pendidikan agama Islam.

Kata kunci: Model Pembelajaran Inkuiri, Pendidikan Agama Islam, Pendidik, Peserta Didik, Toleransi

Jurnal Pendidikan Agama Islam Al-Thariqah Vol. 6, No. 1, Januari - Juni 2021 Received : 31 Desember 2020; Accepted : 22 Juni 2021; Published : 30 Juni 2021

*Corresponding Author : khikiyayu@gmail.com 


\section{PENDAHULUAN}

Pendidikan Islam merupakan sarana penting untuk menamamkan akhlak yang baik pada peserta didik dan menjadikan mereka sebagai insan kamil. Ramayulis (2015) mengemukakan, secara umum pendidikan Islam juga mempunyai tujuan berupa self realization yaitu sebuah tindakan berdasarkan ilmu yang telah dia pelajari baik di sekolah, keluarga dan lingkungan sehingga antara ilmu dan amal itu seimbang, tidak hanya sekadar pengetahuan saja tanpa aksi yang baik.

Proses pembelajaran pendidikan agama Islam masih menjadi hal yang hangat untuk diperbincangkan dan diteliti dikarenakan penerapan pembelajaran pendidikan agama Islam masih belum maksimal. Penelitian Ginanjar, Darmawan \& Sriyono (2019) menemukan bahwa proses belajar mengajar masih rendah sekali ditandai dengan hanya 15,6\% peserta didik yang berani untuk menyampaikan sebuah pertanyaan ataupun menjawab pertanyaan dari seorang pendidik. Musrifah (2018) dalam penelitiannya menemukan bahwa lemahnya pendidikan di Indonesia dikarenakan sistem pembelajaran yang keliru yang membentuk peserta didik menjadi manusia pasif.

Penelitia lainnya dikemukakan Nursoh \& Ahsani (2020) bahwa ada beberapa hal yang menjadikan proses belajar mengajar pendidikan agama Islam cenderung membosankan bagi peserta didik dikarenakan seorang pendidik yang kurang kreatif, inovatif dan salah memilih model pembelajaran yang digunakan. Pendidik juga cenderung menggunakan metode ceramah yang terkesan lebih efektif dan efisien. Zulvawati, Isnaini \& Intihana (2019) dalam penelitian yang telah mereka lakukan menjelaskan pemilihan metode atau model pembelajaran sangat berpengaruh bagi peserta didik. Peserta didik yang pasif sejatinya dikarenakan mereka tidak menerima pembelajaran yang seutuhnya atau bermakna.

Menurut Bahri (2019) di dalam memberikan kritikan tentang model pembelajaran PAI yang masih bersifat tradisonal sementara zaman sudah semakin mencapai titik klimaks. Sejauh ini proses pembelajaran PAI hanya berorientasi pada materi-materi tanpa dan sedikit sekali aplikasi. Realitas di lapangan juga menunjukkan bahwa metode ceramah merupakan suatu hal yang lumrah dalam proses belajar mengajar untuk PAI. Akan tetapi, implementasi metode ceramah belum bisa menghasilkan proses belajar mengajar yang bermakna. Hal tersebut disimpulkan berdasarkan situasi kelas yang tidak kondusif dalam proses belajar mengajar, peserta didik sangat pasif, dan tidak mampu menjadikan peserta didik aktif dalam pembelajaran sehingga proses belajar mengajar dapat dikatakan kurang efektif.

Pada realitanya, diketahui bahwa zaman semakin berkembang dan banyak mengalami perubahan baik dalam sisi pemikiran, konsumsi maupun gaya hidup (life style). Maka hal ini mengharuskan proses pembelajaran mengikuti perkembangan zaman baik dari filosofi, visi dan misi, metode, tujuan, evaluasi, sumber daya manusia, dan arah pendidikan untuk kemajuan masa depan. Pada zaman revolusi industri 4.0 ini pendidik dituntut mampu melakukan inovasi dalam proses belajar mengajar dan mengarahkan peserta didik untuk tidak terpaku pada guru sebagai pemberi informasi satu-satunya. Menurut Priyanto (2020) dalam penelitiannya memberikan sebuah pandangan bahwa pembelajaran PAI harus memiliki semangat untuk mengarah kepada masa depan dengan nilai-nilai agama dan karakter bukan sekadar pemahan kognitif yang dijabarkan dengan angka-angka belaka.

Penjabaran di atas merupakan beberapa penelitian yang membahas masalah penerapan model pembelajaran 
yang kurang efektif untuk PAI dan terdapat solusi-solusi yang ditawarkan juga dalam penelitian tersebut. Maka, pada penelitian ini memberikan sebuah tawaran solutif yaitu berupa model pembelajaran inkuiri dalam pembelajaran pendidikan agama Islam diterapkan di SMP Negeri 1 Jenangan, Kecamatan Jenangan, Kabupaten Ponorogo, Jawa Timur. Model pembelajaran ini mengarahkan peserta didik untuk lebih progresif dan aktif memahami makna dari sebuah pembelajaran. Hal itu selaras dengan pendapat Fitriani and Yanuarti (2018) dalam penelitian bahwa peserta didik harus mampu memahami benarbenar pengetahuan yang telah dia dapatkan agar menjadi muslim yang memiliki kecerdasan mumpuni untuk memahami masalah-masalah yang sedang terjadi.

Berdasarakan hal tersebut, untuk menjadikan peserta didik lebih aktif, berpikir kritis dan memiliki daya nalar yang mumpuni atau dapat dikatakan sebagai Higher Order Thinnking Skills (HOTS) seorang pendidik perlu melakukan inovasi model pembelajaran. Penelitian ini berupa implementasi model pembelajaran inkuiri dalam materi toleransi agar dapat terealisasi di kehidupan nyata. Fokus dari penelitian ini adalah menganalisis impelementasi model pembelajaran inkuiri baik dari segi manfaat, kelebihan dan kekurangannya untuk menjadikan peserta didik memahami ilmu agama seutuhnya khususnya dalam hal toleransi. Sehingga, peserta didik tidak menjadi orang-orang yang intoleran terhadap organisasi-organisasi lain, dan umat beragama lainnya dan diharapkan mampu menjadi muslim yang kaffah dan memiliki sikap tasamuh.

\section{KONSEP TEORI}

\section{Model Pembelajaran Inkuiri}

Proses belajar mengajar tidak terlepas dari pintarnya seorang pendidik dalam menentukan model pembelajaran apa yang hendak digunakan. Menurut Prihartini, et al. (2019) seorang pendidik bukan hanya sekadar tugas profesi, tetapi sebuah tanggung jawab kepada peserta didik untuk memberikan suasana pembelajaran yang baik dan dengan model pembelajaran yang terbaik.

$$
\text { Menurut Tambak }
$$

menegaskan bahwa model pembelajaran merupakan sebuah gambaran dari awal hingga akhir dan disajikan oleh pendidik dalam proses belajar mengajar. Secara singkatnya, model pembelajaran itu berisi mengenai pendekatan, metode, suatu strategi, dan teknik yang dipakai oleh pendidik dalam memberikan ilmu atau pengetahuan kepada peserta didik. Menurut Gunarto (2013) model pembelajaran itu memiliki arti sebuah prosedur atau pola yang sistematis dan digunakan dalam proses belajar mengajar sehingga memberikan kemudahan bagi peserta didik. Selain itu, menurut Nurdyansyah (2016) model pembelajaran suatu hal yang berkaitan erat dengan pendekatan, strategi dan teknik mengajar dari seorang pendidik. Menurut Tayeb (2017) dalam penelitiannya model pembelajaran merupakan sebuah gagasan yang utama untuk memberikan gambaran bagaimana seorang pendidik akan menyampaikan pengetahuan kepada peserta didik.

Ada beberapa model-model pembelajaran yang dapat mengarahkan peserta didik untuk mengembangkan karakter dalam pembelajaran yaitu model pembelajara berpogram, model pembelajaran berbasis quantum learning, model pembelajaran lesson study, model pembelajaran berbasis cooperatif learning, dan model pembelajaran inkuiri (Ramayulis, 1990; Tambak, 2014).

Model pembelajaran inkuiri adalah proses untuk mencari tahu atau memahamai sebuah informasi. Sementara itu, secara luas ditegaskan bahwa model pembelajaran inkuiri merupakan model pembelajaran yang berorientasi untuk 
memecahkan sebuah masalah. Pada model pembelajaran ini, Peserta didik dan pendidik bekerja sama untuk menjadikan pembelajaran menjadi lebih bermakna sehingga peserta didik memiliki wawasan yang kompleks dan mampu membuat analisis terhadap suatu masalah dengan logis. Selain itu, dalam model pembelajaran inkuiri peserta didik menjadi subyek dalam pembelajaran (Fadli, 2019). Model pembelajaran inkuiri selalu berkaitan dengan metode problem solving. Model pembelajaran inkuiri ini sendiri juga merupakan pengembangan dari model pembelajaran discovery learning. Ada beberapa hal yang tercakup dalam model pembelajaran inkuiri yaitu mencari sebuah masalah, memecahkan sebuah masalah, membuat analisis masalah dan kesimpulan (Saharullah, et al. 2019).

Setiap model pembelajaran memiliki tujuan masing-masing. Adapun tujuan model pembelajaran inkuiri yaitu: Pertama, menjadikan peserta didik lebih mampu mengembangkan sikap. Kedua, mengasah kemampuan berpikir dari peserta didik sehingga mampu berpikir lebih kritis, aktif dan memiliki nalar yang tinggi. Ketiga, membuat peserta didik mempunyai motivasi yang tinggi untuk mengikuti kegiatan belajar (Sariah, 2017).

Menurut Solichin (2017) dalam penelitiannya yang membahas model pembelajaran PAI, ada beberapa prinsip dalam pembelajaran berbasis inkuiri. Prinsip-prinsip yang digunakan pada pembelajaran ini adalah; Pertama, prinsip untuk memberikan kemajuan intelektual kepada peserta didik. Kedua, prinsip yang mengajak peserta didik untuk melakukan interaksi. Ketiga, prinsip yang mengarahkan peserta didik untuk aktif bertanya sehingga pembelajaran tidak pasif. Keempat, prinsip yang mengajarkan peserta didik terbuka dalam pemikiran sehingga tidak mengalami kejumudan. Selain itu, prinsip-prinsip lainnya dalam pembelajaran inkuiri berupa orientasi dari pembelajaran inkuiri mengarahkan pada perkembangan intelektual, adanya proses interaksi yang mendalam antara peserta didik dengan pendidik, berorientasi pada prinsip untuk bertanya dan berpikir.

$$
\text { Menurut Fadli (2019) dalam }
$$
penelitiannya di Pekalongan, untuk menerapkan pembelajaran inkuiri di diperlukan langkah-langkah: Langkah awal, yaitu meliputi pendidik harus merumuskan pembelajaran terlebih dahulu berupa topik yang akan dibahas, pendidik membuat rumusan tujuan khusus atau disebut dengan kompetensi dasar, dan memberi penjelasan tentang proses atau jalannya pembelajaran dengan model inkuiri tersebut. Langkah kedua, adalah pelaksanaan. Pada langkah pelaksanaan ini, ada beberapa hal yang harus dilakukan oleh pendidik, yaitu pendidik memberikan masalah yang sesuai dengan tema yang akan dibahas sehingga peserta didik mampu mengembangkan daya nalarnya, pendidik memberikan kesempatan bagi pendidik untuk membuat pertanyaan dan peserta didik diharuskan memecahkan masalah yang sudah diberikan baik dari teman ataupun pendidik. Langkah ketiga, yaitu pendidik dan peserta didik mencoba untuk membahas masalah yang sudah dicari jalan keluarnya dengan menggunakan dasar atau landasan yang akurat.

Selaras dengan pendapat tersebut, Budiman and Munfarid (2017) dalam penelitiannya yang membahas mengenai penerapan pembelajaran inkuiri terdapat beberapa proses yang harus dilakukan yaitu: (1) Pendidik mengajukan atau melontarkan sebuah pertanyaan yang berkaitan dengan materi pembelajaran. Pertanyaan tersebut bisa berupa fenomena yang terjadi misalkan kasuskasus agama dalam Indonesia dan berkaitan erat dengan materi. (2) Peserta didik membuat rumusan masalah yang telah diajukan oleh pendidik. (3) Membuat sebuah dugaan sementara atau hipotesis. (4) Mengumpulkan informasi-informasi 
yang valid untuk menjawab persoalan tersebut. (5) Membuat analisa dan menyimpulkan dengan tepat.

Menurut Anggriani (2019) dalam penelitian di Bengkulu membahas mengenai pembelajaran inkuiri memiliki tujuan yang penting untuk peserta didik. Ada beberapa kelebihan dari pembelajaran inukiri, meliputi membantu peserta didik untuk lebih siap dan tanggap terhadap materi pembelajaran, memberikan gairah kepada peserta didik dalam proses belajar karena dorongan motivasi, memberikan sebuah peluang (opportunity) bagi peserta didik untuk meningkatkan level kognitif mereka. Secara praktisnya dapat diambil lima poin tentang kelebihan pembelajaran inkuiri yaitu menggunakan pengetahuan yang relevan, siswa dapat memandang subtansi materi, memotivasi peserta didik, mempererat hubungan pendidik dan peserta didik, dan memberikan transfer of knowledge dengan kualitas unggul. Untuk kekurangan dari pembelajaran inkuiri sendiri yaitu membutuhkan pendidik yang memiliki intelektual yang mumpuni, peserta didik juga harus dituntut untuk mengubah gaya belajar yang cenderung pasif menjadi lebih aktif, dan guru harus mampu mengolah manajemen waktu.

\section{Hakikat Pendidikan Agama Islam}

Menurut Mahmud

pendidikan Islam berasal dari istilahistilah Islam yaitu al-tarbiyah, al-ta'lim, alta'dib. Ketiga istilah tersebut memiliki pengertian yang berbeda, namun secara subtansinya adalah sama-sama untuk mendidik, membimbing, dan menjadikan seseorang atau peserta didik memiliki sebuah pemahaman mengenai Islam yang berdasarkan Al-Qur'an dan As-Sunah sehingga peserta didik mampu membuat keputusan mengenai mana jalan yang benar dan buruk untuk dirinya sendiri. Sementara itu, menurut Ni'amah (2021) dalam penelitiannya yang membahas pendidikan Islam menurut sudut pandang
Imam Al-Ghazali menjelaskan bahwa pendidikan Islam itu sendiri suatu ilmu yang harus dimiliki oleh peserta didik sebagai seorang muslim. Pendidikan Islam memberikan nilai-nilai rohani kepada peserta didik untuk memahami Islam dengan baik dan berorientasi kepada nilainilai moral. Selajan dengan pendapat Harahap and Siregar (2017) dalam penelitian yang telah mereka lakukan memberikan sebuah padangan bahwa pendidikan Islam bukan hanya tentang materi-materi saja. Akan tetapi, pendidikan Islam adalah ilmu yang wajib didapatkan oleh peserta didik dalam rangka hifz an-nafs.

Menurut Hidayah \& Mudrikah (2020) pendidikan agama Islam adalah proses transfer pengetahuan atau ilmu kepada peserta didik agar mereka mampu mengembangkan potensinya sebagai pegangan untuk mengendalikan diri, dan memiliki akhlak yang mulia. Sementara untuk pengertian singkatnya pendidikan agama Islam adalah pemberian pengetahuan kepada peserta didik untuk mengajarkan nilai-nilai Islam agar mereka lebih dekat dengan Allah.

Menurut Ramayulis (2015) dalam filsafat pendidikan Islam pada lampiran UU Nomor 22 Tahun 2006 yang di dalamnya terkandung kurikulum pendidikan agama Islam dengan tujuan untuk menghasilkan output manusia yang memiliki kesempurnaan iman, akhlak, takwa serta berkontribusi dalam membangun sebuah peradaban. Kemudian, karakteristik dari materi dalam pendidikan agama Islam adalah: (1) Pelajaran yang dikembangkan dari ajaranajaran agama Islam. (2) PAI sejatinya adalah pelajaran yang penting dan terikat dengan subtansi mata pelajaran lain secara tidak langsung. (3) PAI memiliki tujuan menghasilkan peserta didik memiliki karakter yang Islam dan menjunjung tinggi adab. (4) Pelajaran yang sesuai dengan tuntunan dari AlQur'an dan Al-Hadis. (5) Prinsip dalam 
pembelajaran PAI ada tiga yaitu berdasarkan dari akidah, akhlak dan syariat. Menurut Ningsih (2019) dalam penelitian di Banyumas yang memiliki fokus pentingnya pendidikan Islam di era revolusi industri 4.0 adalah: (1) Menekan terjadinya penyimpangan dalam moral. (2) Sebagai dasar atau pedoman bagi peserta didik. (3) Membentuk karakter dan pribadi menjadi lebih baik karena pada dasarnya nilai karakter itu berdasarkan dari tiga sumber yaitu sikap religius, jujur dan toleransi.

\section{Hakikat Pendidik dan Perannya dalam Pembelajaran Inkuiri}

Seorang pendidik memiliki pengaruh yang besar agar model pembelajaran inkuiri dapat diaplikasikan. Menurut Ramayulis (2015) dalam filsafat pendidikan Islamnya, asal kata pendidik itu dari kata 'didik' yang memiliki arti merawat, menjaga dan memelihara agar seseorang yang dididik memiliki kepribadian luhur, sopan, beradab dan memiliki intelektual tinggi. Pengertian lain tentang pendidik dapat dikatakan sebagai orang yang sudah dewasa dan mengemban tanggung jawab pada orang lain.

Menurut Zulmy (2020) dalam perspektif Al-Qur'an ada beberapa pengertian pendidik yaitu: (1) Murrabi, yaitu diambil dari kata raba-yarbu sehingga mempunyai arti bertambah. Maksud dari kata tersebut adalah bahwa usaha untuk mendidik peserta didik sehingga memiliki kemampuan yang meningkat atau bertambah. (2) Mu'allim, yaitu orang yang telah mengajar, atau dalam keadaan mengajar. Maka dapat diartikan mu'allim merupakan orang yang memberikan ilmu (transfer of knowledge). (3) Mu'addib, yaitu seorang pendidik yang mengupayakan peserta didik belajar tentang adab. (4) Mudaris, yaitu seseorang yang memiliki kemampuan intelektual memadai sehingga mampu memberikan pembelajaran yang terbaik untuk peserta didik. Untuk menjadi seorang pendidik harus memenuhi kriteria atau persyaratan. Menurut Mahmud (2011) dalam buku pemikiran Islamnya syarat menjadi seorang pendidik adalah: (1) Dewasa. (2) Sehat baik dalam jasmani maupun rohani. (3) Menguasai ilmu yang didalami. (4) Memiliki kepribadian yang baik.

Seorang pendidik memiliki tugastugas yaitu: (1) Sebagai seorang manajer, di mana seorang guru harus memimpin dan mengolah kelas dengan baik sehingga tujuan pembelajaran mampu dicapai. (2) Sebagai seorang aktor, jadi seorang pendidik adalah pemeran utam dalam pembelajaran. Perannya tersebut berupa memberikan pembelajaran yang bermakna kepada peserta didik. (3) Sebagai orang superviour, jadi seorang pendidik harus mengarahkan pembelajaran yang kreatif dan menjadikan daya nalar peserta didik tinggi. (4) Sebagai leader, pendidik merupakan seorang pemimpin bagi peserta didik Prihartini, dkk (2019). Menurut Irman RN (2019) dalam penelitiannya di kota Parepare, agar tugas - tugas itu mampu diemban oleh pendidik maka pendidik harus dibekali ilmu pengetahuan, harus memiliki kemampuan untuk berinteraksi dengan peserta didik dan melakukan action yang terbaik

Menurut Ramayulis (1990) dalam metodologi pendidikan Islam, peran pendidik sangat penting untuk mempermudah proses pembelajaran, pembelajaran tidak bisa berjalan tanpa pendidik maupun peserta didik. (1) Pendidik harus memilih suatu masalah yang dianggap menarik dan memberikan pengetahuan bagi peserta didik. (2) Pendidik harus membentuk kelompok dengan cara seimbang, jadi harus tahu kelebihan dan kekurangan peserta didiknya. (3) Pendidik memberi penjelasan tugas secara detail kepada peserta didik sehingga tidak terjadi salah tafsir (miss communication with the 
students). Hal ini sangat diperlukan dikarenakan apabila peserta didik tidak diarahkan maka akan menjadikan mereka salah menerima informasi sehingga tugas yang mereka kerjakan juga salah. Sekali lagi, tugas di sini adalah memecahkan masalah. (4) Pendidik memberikan penjelasan di akhir pembelajaran dan menguatkan informasi agar peserta didik lebih mudah memahami. Jadi peran pendidik di sini adalah hanya sekadar memberikan kemudahan dalam jalannya pembelajaran atau disebut sebagai fasilitator dan mengevaluasi hasil pembahasan peserta didik atau disebut sebagai evaluator.

Selain itu, menurut Yuliarti (2019) dalam penelitiannya di Pekanbaru, seorang pendidik juga harus memiliki soft skills baik dalam interpersonal maupun intrapersonal. Soft skills interpersonal meliputi kemampuan untuk melakukan komunikasi dengan baik kepada peserta didik, kemampuan untuk cepat menyesuaikan diri dengan keadaan lingkungan tempatnya mengajar, dan mampu mengomunikasikan serta membuat karya-karya ilmiah. Untuk soft skills intrapersonal meliputi seorang pendidik mampu menyesuaikan dirinya dengan norma-norma yang berlaku, memiliki sikap yang berwibawa, sikap percaya diri yang tinggi, memiliki etos kerja yang tinggi tanpa mengenal lelah, memiliki rasa bangga terhadap profesinya, dan mempunyai tanggung jawab terhadap pekerjaannya. Untuk kompetensi kompetensi yang harus dimiliki pendidik agar memudahkan proses belajar mengajar yaitu pendidik harus mengajar sesuai dengan kapasitas dan kompetensi yang dia miliki, mempunyai intregritas yang tinggi, dan menguasai seluk beluk dunia pendidikan secara kompleks serta mampu merancang pembelajaran dengan kreatif maupun inovatif (Jaenuri, 2017).

Menurut Buchari (2018) peran pendidik dalam mengelola kelas untuk mempermudah menerapkan model pembelajaran inkuiri yaitu: (1) Menyusun perencanaan tentang program pembelajaran. (2) Mengorganisasikan peserta didik. (3) Memberikan sebuah motivasi kepada peserta didik. (4) Membuat evaluasi hasil pembelajaran sehingga mampu menjadi pertimbangan ke depannya.

\section{Peserta Didik dan Manfaat Pembelajaran Inkuiri}

Peserta didik adalah seseorang yang berusaha untuk mengembangkan segala potensi yang ada di dalam dirinya agar mampu menentukan arah dan tujuannya dalam sebuah kehidupan dan bermanfaat bagi orang-orang di sekitarnya. Dalam falsafah pendidikan Islam peserta didik dikatakan sebagai al-insan, atau al-basyr yang merujuk pada suatu fase yang berkembang menuju ke arah yang baik (Usman \& Hadi, 2020).

Menurut Harapap (2016) bahwa peserta didik memiliki pengertian seseorang yang belum dewasa, maka dari itu ia sangat memerlukan sebuah pengajaran dan memiliki ciri-ciri: (1) Seseorang yang lemah dan tidak berdaya. (2) Seseorang yang mempunyai tekad kuat atau memiliki kemauan yang keras. (3) Seseorang yang ingin menjadi dirinya sendiri tanpa meniru orang lain.

Dalimunthe (2017) mengemukakan bahwa peserta didik memiliki hakikat: (1) Seseorang yang bukan miniature dari orang dewasa di mana mereka mempunyai kebiasaan tersendiri terhadap dunia mereka. (2) Seseorang yang masih berada dalam tahap perkembangan dalam periode - periode tertentu. (3) Seseorang yang memiliki kebutuhan biologis baik rasa kasih sayang, rasa untuk dihargai dan aktualisasi diri. (4) Seseorang yang mempunyai perbedaan antara individu satu dengan yang lainnya. (5) Seseorang yang menjadi objek penelitian. Selain itu, peserta didik dapat dikatakan sebagai seseorang yang memiliki tanggung jawab terhadap dirinya sendiri sebagai seorang 
manusia. Di mana pada dasarnya hal tersebutlah yang menjadikan sebuah pendidikan ada (Syarif, 2017)

Di sisi lain, Nurfadilah (2019) mengemukakan bahwa peserta didik memiliki kebutuhan-kebutuhan yaitu: (1) Kebutuhan yang berkaitan dengan fisik. Proses pertumbuhan fisik peserta didik dibagi menjadi tiga tahapan mulai dari usia 0-7 tahun, usia 7-14 tahun dan usia 14-21 tahun. (2) Kebutuhan yang berhubungan dengan aspek sosial, yaitu sebuah hubungan yang berkaitan dengan masyarakat di mana peserta didik melakukan sebuah interaksi dengan masyarakat. (3) Kebutuhan untuk memperoleh sebuah pengakuan, yaitu peserta didik dalam hal ini ingin dihargai dan dihormati. (4) Kebutuhan dalam prestasi. (5) Kebutuhan untuk dicintai. Sementara menurut Ramayulis (2015) dalam filsafat pendidikan Islam kebutuhan peserta didik dibagi menjadi dua yaitu kebutuhan primer dan kebutuhan sekunder. Kebutuhan primer itu berupa kebutuhan untuk makan, dan minum. Untuk kebtuhan sekunder meliputi kebutuhan rasa kasih sayang, harga diri, dan kebutuhan untuk sukses.

Berdasarkan penjabaran di atas yang berkaitan dengan peserta didik ada beberapa manfaat penerapan model pembelajaran inkuiri untuk peserta didik meliputi: (1) Menjadikan peserta didik lebih aktif. (2) Pembelajaran inkuiri menjadi sebuah terobosan yang tidak membuat peserta didik merasa bosan dalam pembelajaran. (3) Menjadikan peserta didik untuk senantiasa berpikir dengan logis dan kritis (Mujiburrohman, 2018).

\section{Relasi Revolusi Industri dan Model Pembelajaran Berbasis Inkuiri}

Menurut Prasetyo \& Sutopo (2018) revolusi industri pertama kali dipelopori oleh Friedrich Engles dan Auguste Blanqul sekitar abad pertengahan ke-19. Revolusi industri 4.0 adalah sebuah perubahan yang sangat klimaks pada bidang industri. Revolusi industri 4.0 ini mengacu pada mesin-mesin dan peran manusia seolah digantikan dengan mesin-mesin dan robot-robot yang memang dianggap lebih mampu berkerja secara cepat dan tepat daripada manusia itu sendiri. Revolusi industri untuk yang pertama kali berkembang di Jerman. Sejatinya revolusi industri dimulai dari revolusi industri pertama, kedua, ketiga dan keempat.Kemudian di Jepang juga sudah ada revolusi industri 5.0 yang lebih mengarah pada manusia (society) yang menjadikan manusia sebagai pusat. Revolusi industri 4.0 secara tidak langsung membuat dampak (impact) yang besar terhadap dunia pendidikan.

Perkembangan pendidikan mesti dilakaukan inovasi oeh semua para pemangku kepentingan agar pendidikan itu selaras dengan perkembangan zaman dalam membangun peradaban mulai. Maka tantangan-tantangan yang dihadapi dunia pendidikan adalah: (1) Pendidikan harus mampu melakukan berbagai inovasi baik dari sisi strategi dan model pembelajaran, pemakaian alat pembelajaran dan menggunakan teknologi dalam proses pembelajaran. (2) Peserta didik harus mampu menjadi SDM (Sumber Daya Manusia) yang mahir dalam segala hal, baik dari segi pemikiran dan pemakaian teknologi. (3) Peserta didik harus mengedepankan literasi. (4) Model pembelajaran yang diterapkan untuk peserta didik harus inovatif, kreatif dan mengarahkan peserta didik menjadi SDM yang berkualitas (Saputra, 2020). Selain itu, tantangan lain yang harus dihadapi dunia pendidikan meliputi: (1) Pendidikan harus mempunyai sarana dan prasarana yang mumpuni bagi peserta didik dan pendidik. (2) Pendidikan harus berproses kepada pelatihan, dan pembelajaran yang inovatif. (3) Pendidikan harus mampu menjadikan peserta didik paham betul terhadap status kewarganegaraannya dan nilai-nilai yang selaras dengan pancasila 
sehingga menjadikan pendidikan yang berkarakter (Reflianto and Syamsuar, 2018).

Berdasarkan penjabaran di atas mengenai revolusi industri 4.0 yang menekankan pada pembelajaran inovatif, kreatif dan mengarahkan peserta didik memiliki intelligence yang tinggi maka hal tersebut berkaitan erat dengan model pembelajaran inkuiri. Menurut Muhali (2018) pembelajaran inkuri dapat dijadikan sebagai salah satu solusi bagi pendidik agar menghasilkan SDM yang berkualitas dalam wawasan dan aplikasinya. Pembelajaran inkuiri menekankan pada eksplorasi di mana dalam proses pembelajaran ada tukar ideide antara pendidik maupun peserta didik, pembelajaran inkuiri menekankan pada penyelidikan dan keterampilan peserta didik, dan materi dapat diterapkan secara nyata dalam kehidupan sehari-hari.

\section{METODE PENELITIAN}

Metode penelitian yang dipakai dalam penelitian ini adalah menggunakan metode kualitatif dengan menggunakan studi kasus. Menurut Suryabrata (2015) metode kualitatif merupakan metode yang menitik beratkan pada hasil penulisan menggunakan penyajian secara deskriptif tidak berupa angka-angka.

Informan dalam penelitian ini adalah; (1) Ibu Iswantini, S.Pd., selaku Kepala SMP Negeri 1 Jenangan, Kecamatan Jenangan, Kabupaten Ponorogo, Jawa Timur, Indonesia; (2) Bapak Drs. Mulyadi selaku guru pendidikan agama Islam di SMP Negeri 1 Jenangan Jenangan, Kecamatan Jenangan, Kabupaten Ponorogo, Jawa Timur, Indonesia; (2) Ibu Hartiningtyas, S.Pd., selaku guru pendidikan agama Islam di SMP Negeri 1 Jenangan, Kecamatan Jenangan, Kabupaten Ponorogo, Jawa Timur, Indonesia. Teknik pengumpulan data pada penelitian ini menggunakan teknik wawancara mendalam. Wawancara pada penelitian ini dilakukan sejak tanggal 10
Agustus 2020 - 12 Agustus 2021 kepada Bapak Mulyadi dan Ibu Hartiningtyas selama dua jam. Wawancara ini dibagi menjadi dua sesi yaitu wawancara pertama berkaitan dengan pertanyaan "bagaimana penerapan model pembelajaran inkuiri dalam proses belajar mengajar PAI?". Wawancara kedua bertujuan untuk menggali kemudahan, hambatan-hambatan dan manfaat dalam menerapkan model pembelajaran inkuiri dengan bengan perspektif kelebihan dan kekurangan dari pembelajaran model inkuiri ketika diterapkan.

Untuk Analisis data dalam penelitian ini adalah menggunakan analisis data dari Miles \& Huberman. Analisis data tersebut memiliki tahapan berupa membuat terlebih dahulu reduksi data, melakukan presentasi data-data yang didapatkan, dan tahap terakhir berupa menarik kesimpulan dari data tersebut (Ibrahim, 2018). Analisis data ini dimulai dengan menggali data melalui informan-informan dalam penelitian ini. Data-data yang dikumpulkan tadi direduksi dengan membuang hal-hal yang tidak penting dalam penelitian ini dan untuk mereduksi data observer berdiskusi dengan teman sejawat. Setelah itu menyajikan data (displaying), di mana di dalamnya datadata yang penting disajikan dan kemukingan terjadi penarikan sebuah kesimpulan. Untuk tahap terakhir adalah menarik kesimpulan. Pada tahap ini, peneliti mengambil makna dilaik makna dengan mengeksplor hasil-hasil wawancara sehingga memiliki fokus yang jelas sesuai dengan tujuan penelitian.

\section{HASIL DAN PEMBAHASAN}

\section{Implementasi Pembelajaran Inkuiri} Pada Materi Pembelajaran Toleransi

Implementasi model pembelajaran inkuiri pada pelajaran PAI memiliki langkah-langkah agar pembelajaran tersebut berjalan dengan baik. Berdasarkan wawancara dengan seorang guru M: "Penerapan model pembelajaran 
inkuiri itu meliputi: Pertama, seorang pendidik harus memberikan rangsangan atau pancingan terhadap peserta didik dengan menggunakan pertanyaan mengenai kaum-kaum intoleran di Indonesia khususnya terorisme. Kedua, pendidik membuat kelompok-kelompok kecil sebanyak 4-5 orang yang mana peserta didik disuruh untuk memecahkan masalah yang ada. Dan disuruh untuk menguji permasalahan tersebut dan bagaimana solusinya. Ketiga, Pendidik memberikan selembar kertas untuk menulis hasil diskusi dengan kelompoknya masing-masing dengan memberikan argumen yang berdasar misalkan ayat Al-Qur'an dan hadis, atau yang lainnya yang menyangkut dengan bab toleransi. Keempat, pendidik meminta peserta didik untuk membuat kesimpulan dengan maju di depan kelas dengan perwakilan dari ketua kelompok kemudian kelompok lain harus memberikan pertanyaan kepada mereka yang maju di depan kelas agar menambah pemahaman mereka. Ketika kegiatan ini dilakukan maka pendidik akan memberikan apresiasi berupa poin bagi peserta didik yang aktif bertanya. Kelima, pada akhir pembelajaran, pendidik menyimpulkan tentang sikap radikal yang bertentangan dengan Q.S Al-Kafirun ayat 6 dan menjelaskan bahwa radikalisme adalah hal yang seharusnya tidak boleh dilakukan di Indonesia".

Sementara itu, berdasarkan wawancara dari seorang guru $\mathrm{H}$ penerapan pembelajaran PAI pada materi toleransi yaitu: "Dalam menerapkan model pembelajaran inkuiri untuk materi toleransi meliputi membuat sebuah pertanyaan yang berkaitan dengan terosisme di Indonesia terlebih dahulu. Selanjutnya, kita meminta peserta didik untuk memecahkan masalah tersebut yang berdasarkan data-data yang valid misalkan dari buku dan internet dengan teman sebangku. Jadi, pada sekolahan ini Handpone boleh digunakan asal dengan syarat untuk pembelajaran. Dari data-data tersebut nanti peserta didik membuat sebuah analisis mengenai terosisme yang mana harus ada kaitannya dengan toleransi dalam Q.S Al-Kafirun ayat 1-6. Setelah mereka membuat analisis, saya menyuruh untuk maju dan menjelaskan hasil diskusi dengan teman-teman sebangku. Hal tersebut menjadikan suasana kelas lebih hidup, karena pada saat mereka maju harus ada peserta didik lainnya yang bertanya".

Guru (M) mengemukakan bahwa, "Saya selalu mempersiapkan langkahlangkah model pembelajaran inkuiri dalam setiap pembelajaran yang saya lakukan. Langkah awal, saya merumuskan pembelajaran terlebih dahulu berupa topik yang akan dibahas, lalu saya membuat rumusan tujuan khusus atau disebut dengan kompetensi dasar, dan memberi penjelasan tentang proses atau jalannya pembelajaran dengan model inkuiri tersebut. Langkah kedua, yaitu pelaksanaan. Pada tahap ini, ada beberapa hal yang saya lakukan yaitu memberikan masalah yang sesuai dengan tema yang akan dibahas sehingga peserta didik mampu mengembangkan daya nalarnya, Saya memberikan kesempatan bagi peserta didik untuk membuat pertanyaan dan peserta didik diharuskan memecahkan masalah yang sudah diberikan baik dari teman ataupun pendidik. Langkah ketiga, yaitu pada langkah ini saya dan peserta didik mencoba untuk membahas masalah yang sudah dicari jalan keluarnya dengan menggunakan dasar atau landasan yang akurat."

Kepala sekolah mengemukakan bahwa "guru pendidikan agama Islam dalam evaluasi kami menerapkan pembelajaran inkuiri dengan beberapa proses yang harus dilakukan yaitu: (1) Guru mengajukan atau melontarkan sebuah pertanyaan yang berkaitan dengan materi pembelajaran. Pertanyaan tersebut bisa berupa fenomena yang terjadi 
misalkan kasus-kasus agama dalam Indonesia dan berkaitan erat dengan materi. (2) Peserta didik membuat rumusan masalah yang telah diajukan oleh pendidik. (3) Membuat sebuah dugaan sementara atau hipotesis. (4) Mengumpulkan informasi - informasi yang valid untuk menjawab persoalan tersebut. (5) Membuat analisa dan menyimpulkan dengan tepat."

Guru (M) mengutarakan bahwa sangat penting diterapkan oleh semua guru dalam pembelajaran pendidikan agama Islam, karena membantu peserta didik untuk lebih siap dan tanggap terhadap materi pembelajaran, memberikan gairah kepada peserta didik dalam proses belajar karena dorongan motivasi, memberikan sebuah peluang (opportunity) bagi peserta didik untuk meningkatkan level kognitif mereka. Secara praktisnya dapat diambil lima poin tentang kelebihan pembelajaran inkuiri yaitu menggunakan pengetahuan yang relevan, siswa dapat memandang subtansi materi, memotivasi peserta didik, mempererat hubungan pendidik dan peserta didik, dan memberikan transfer of knowledge dengan kualitas unggul. Untuk kekurangan dari pembelajaran inkuiri sendiri yaitu membutuhkan pendidik yang memiliki intelektual yang mumpuni, peserta didik juga harus dituntut untuk mengubah gaya belajar yang cenderung pasif menjadi lebih aktif, dan guru harus mampu mengolah manajemen waktu."

Berdasarkan wawancara dengan dua informa yang merupakan guru PAI di SMP Negeri 1 Jenangan, Kecamatan Jenangan, Kabupaten Ponorogo, Jawa Timur, di atas bahwa penerapan tersebut sudah sesuai dengan teori yang ada. Jadi pada tahaptahap penerapan model pembelajaran inkuiri tersebut sejalan dengan Maryance (2018) dalam penelitiannya di Palembang untuk menerapkan pembelajaran inkuri ada hal-hal yang harus diperhatikan mulai dari memberikan gambaran terhadap materi pembelajaran dengan mengajukan sebuh pertanyaan, peserta didik merumuskan masalah, peserta didik melakukan analisis baik yang dituangkan dalam paragrap bersama dengan kelompok-kelompok kecil, dan tahap terakhir berupa menarik kesimpulan serta mempresentasikan di depan kelas.

Model pembelajaran inkuiri selalu berkaitan dengan metode problem solving. Model pembelajaran inkuiri ini sendiri juga merupakan pengembangan dari model pembelajaran discovery learning. Ada beberapa hal yang tercakup dalam model pembelajaran inkuiri yaitu mencari sebuah masalah, memecahkan sebuah masalah, membuat analisis masalah dan kesimpulan (Saharullah, et al. 2019).

\section{Manfaat Penerapan Pembelajaran Inkuiri pada Materi Toleransi}

Setiap model pembelajaran ketika diterapkan dalam pembelajaran secara langsung akan memberikan dampak (impact) kepada peserta didik. Berdasarkan wawancara dengan sekolah SMP Negeri 1 Jenangan beliau menjelaskan: "Penerapan pembelajaran model inkuiri sejatinya masih baru - baru ini terapkan kurang lebih tiga tahunan. Akan tetapi, ketika kita mengadakan evaluasi pembelajaran guru-guru yang menerapkan pembelajaran inkuiri di sini mengatakan bahwa itu hal yang sangat efektif bagi pendidik agar lebih aktif". Hal tersebut selaras dengan pendapat Nurmayani, et al. (2018) pembelajaran inkuiri memberikan manfaat pada peserta didik untuk berpikir kritis terhadap sesuatu.

Guru M dalam penjelasannya ketika peneliti mengajukan pertanyaan yang terkait dengan manfaat pembelajaran inkuiri dalam materi toleransi beliau mengatakan: "Banyak sekali manfaatnya ketika model pembelajaran inkuiri diterapkan dalam materi - materi yang memang butuh aplikasi di dunia nyata. Saat kita menerapkan model ini kepada peserta didik secara tidak langsung 
mereka akan berpikir melalui merumuskan masalah yaang berkaitan dengan intoleran di Indonesia, ketika itu mereka otomatis juga memberikan sebuah solusi untuk permasalah tersebut dan suatu saat pasti akan berguna dalam kehidupan peserta didik".

\section{Kelebihan dan Kekurangan Pembelajaran Inkuiri}

Setiap pembelajaran memiliki kelebihan dan kekurangan. Berdasarkan hasil wawancara dengan guru $\mathrm{M}$ : "Kelebihan-kelebihan ketika menerapkan model pembelajaran inkuiri adalah peserta didik terlihat nyaman dan senang dengan pembelajaran dikarenakan pembelajaran itu tidak monoton seperti metode ceramah, peserta didik juga bisa berdiskusi dan bertukar ide-ide dan secara tidak langsung mereka belajar untuk berinteraksi dengan teman sekelasnya, peserta didik juga diberikan kesempatan untuk menunjukkan siapa dirinya di hadapan teman-temannya dengan cara mempresentasikan hasil dari diskusi dengan kelompok masing-masing. Sementara untuk kekurangannya itu memang butuh banyak waktu, persiapan, dan pengetahuan yang mumpuni untuk melaksanakan menerapkan model pembelajaran inkuiri. Jadi, ketika seorang guru tidak punya persiapan nanti akan mempersulit penerapannya di kelas".

Sementara itu, menurut hasil wawancara dengan guru $\mathrm{H}$ mengenai kelebihan dan kekurangan pembelajaran inkuiri yaitu: "Kelebihan pembelajaran inkuiri itu memang banyak sekali khususnya untuk zaman yang semakin berkembang ini dikarenakan pembelajaran inkuiri itu mengarahkan peserta didik bahwa pembelajaran itu bukan sekadar teori-teori saja tetapi penerapan. Apalagi dalam materi-materi berupa toleransi seperti ini itu akan memberikan bekas di dalam benak peserta didik untuk memahami betul-betul toleransi. Untuk kekurangan pembelajaran inkuiri ini apabila diterapkan di kelas memang memerlukan banyak waktu, terkadang juga peserta didik yang pasif saat berdiskusi dengan temannya yang aktif seakan tidak seimbang. Akan tetapi, menurut saya bahwa model pembelajaran inkuiri lebih banyak kelebihannya daripada kekurangannya ketika diterapkan".

Berdasarkan wawancara dengan dua informan yang merupakan guru PAI tersebut bahwa kekurangan dan kelebihan dalam menerapkan pembelajaran inkuiri hampir sama dalam penelitian-penelitian yang sebelumnya. Menurut Maryance di Palembang (2018) secara signifikan model pembelajaran inkuiri itu menjadikan peserta didik memahami secara utuh materi pembelajaran dengan bukti hasil tes yang telah dilakukan. Sementara untuk kekurangannya apabila pendidik tidak bisa mengarahkan pembelajaran maka akan menghabiskan banyak waktu karena dalam pembelajaran inkuiri suasana kelas riuh.

\section{PENUTUP}

Penerapan model pembelajaran inkuiri di SMP Negeri 1 Jenangan, Kecamatan Jenangan, Kabupaten Ponorogo, Jawa Timur, Indonesia, bidang studi pendidikan agama Islam, materi toleransi bertujuan untuk menjadikan peserta didik memiliki kreativitas, memiliki intelektual yang tinggi, dan melahirkan peserta didik yang seimbang dalam ilmu agama dan ilmu pengetahuan umum untuk diterapkan dalam kehidupan nyata. Penerapan model pembelajaran di SMP Negeri 1 Jenangan, Kecamatan Jenangan, Kabupaten Ponorogo, Jawa Timur, Indonesia itu meliputi mengajukan pertanyaan kepada peserta didik, mengarahkan peserta didik untuk merumuskan masalah, menganalisa masalah dan membuat kesimpulan dari masalah tersebut. Kelebihan penerapan model pembelajaran inkuiri mata pelajaran pendidikan agama Islam, materi 
toleransi di SMP Negeri 1 Jenangan, Kecamatan Jenangan, Kabupaten Ponorogo, Jawa Timur, Indonesia, meliputi peserta didik menjadi lebih aktif dalam proses pembelajaran. Peserta didik mampu menjalin interaksi dengan temantemannya dan hasil dari pembelajaran toleransi memberikan bekas tersendiri di benak peserta didik. Sementara untuk kekurangannya pendidik terkadang terbentur dengan waktu. Akan tetapi, hal yang paling penting adalah pembelajaran inkuiri mampu mengajak peserta di SMP Negeri 1 Jenangan, Kecamatan Jenangan, Kabupaten Ponorogo, Jawa Timur, Indonesia berpikir secara kritis terhadap hal-hal yang berkaitan dengan dunia Islam agar menjadi muslim yang mampu mengarahkan diri kepada hal-hal yang ma'ruf. Hasil penelitian ini berimplikasi pada pengembangan "teori model pembelajaran inkuiri dalam pembelajaran toleransi" dalam pembelajaran pendidikan agama Islam.

\section{DAFTAR RUJUKAN}

Anggriani, Fetti. "Penerapan Strategi Pembelajaran Inkuiri Untuk Meningkatkan Kemampuan PAI Siswa Kelas VIII B SMP 1 Bengkulu." Jurnal Akademika 15.2 (2019): 5354.

Ahmad, Muhammad Yusuf, Syahraini Tambak, and Uswatun Hasanah. "Pengaruh Kecerdasan Emosional terhadap Penyesuaian Diri Mahasiswa Thailand." Al-Hikmah: Jurnal Agama dan Ilmu Pengetahuan 15.2 (2018): 16-30. https://doi.org/10.25299/alhikmah:jaip.2018.vol15(2).2374.

Ahmad, Muhammad Yusuf, and Syahraini Tambak. "Penanaman Nilai-Nilai Pendidikan Akidah Melalui Mata Pelajaran Sejarah Kebudayaan Islam (SKI)." Al-Hikmah: Jurnal Agama dan Ilmu Pengetahuan 15.1 (2018): 2441.

https://doi.org/10.25299/jaip.2018. vol15(1).1581.

Ahmad, Muhammad Yusuf, Syahraini Tambak, and Mira Syafitri. "Etika Pergaulan Islami Santri Madrasah Aliyah (MA) di Pesantren Jabal Nur Kecamatan Kandis Kabupaten Siak." Al-Hikmah: Jurnal Agama dan Ilmu Pengetahuan 13.2 (2016): 206-226. https://doi.org/10.25299/alhikmah:jaip.2016.vol13(2).1524.

Ahmad, Mawardi. "Hubungan Potensi Akal dengan Kreativitas Belajar Siswa Bidang Studi Pendidikan Agama Islam di SMK Kanada Sakura Indonesia (KANSAI) Pekanbaru." Jurnal Pendidikan Agama Islam AlThariqah 2.1 (2017): 51-72. https://doi.org/10.25299/althariqa h.2017.vol2(1).647.

Ahmad, Mawardi, and Syahraini Tambak. "Penerapan Metode Diskusi Dalam Meningkatkan Hasil Belajar Murid Pada Pelajaran Fiqh." Al-Hikmah: Jurnal Agama Dan Ilmu Pengetahuan $15.1 \quad$ (2018): 64-84. https://doi.org/10.25299/jaip.2018. vol15(1).1585.

Bahri, Samsul. "Pengembangan Pendidikan Islam di Era 4.0." Jurnal Transformatif 3. 2 (2019): 165-174.

Buchari, Agustini. "Peran Guru dalam Pengelolaan Pembelajaran." Jurnal Ilmiah Iqra' 12.2 (2018): 196-205 doi:http://dx.doi.org/10.30984/jii.v 12i2.897.

Budiman, Agus, dan M. Munfarid. "Penerapan Metode Kontekstual Inkuiri dalam Pembelajaran Pendidikan Agama Islam." Jurnal Educatin 1.1 (2017): 35-54. ,doi:http://dx.doi.org/10.21111/edu can.v1i1.1298.

Dalimunthe, Putri Ani. "Peserta Didik dalam Persepktif Pendidikan Islam." Jurnal Pendidikan Bahasa dan Sastra Arab 3.2 (2017): 88-89.

Fadli, Failasuf. "Penerapan Metode Inkuiri dalam Meningkatkan Keterampilan Berpikir Kritis dan Keaktifan Belajar 
Siswa pada Mata Pelajaran PAI di MTS Al-Amin Pekalongan." Jurnal

Kajian Teknologi Pendidikan 4.1 (2019):

$22-24$

doi:http://dx.doi.org/10.17977/um0 39v4i12019p019.

Fitriani, Atika, dan Eka Yanuarti. "Upaya Guru Pendidikan Agama Islam dalam Menumbuhkan Kecerdasan Spiritual Siswa." Jurnal Pendidikan Islam 3.2 (2018):

165-173.

doi:http://dx.doi.org/10.29240/bela jea.v3i2.527.

Ginanjar, Eggi G., et al. "Faktor-Faktor yang Mempengaruhi Rendahnya

Partisipasi Belajar Peserta Didik di SMK." Journal of Mechanical Education 6.2 (2019): 207-208, doi:https://doi.org/10.17509/jmee.v $6 \mathrm{i} 2.21797$.

Gunarto. Model dan Metode Pembelajaran di Sekolah. Unisula Press, 2013.

Hamzah, Desi Sukenti, Syahraini Tambak, and Wisudatul Ummi Tanjung. "Overcoming self-confidence of Islamic religious education students: The influence of personal learning model." Journal of Education and Learning (EduLearn) 14.4 (2020): 582-589.

https://doi.org/10.11591/edulearn. v14i4.16759.

Hamzah, Hamzah, Syahraini Tambak, and Nella Ariyani. "Upaya Guru Pendidikan Agama Islam dalam Pembentukan Kepribadian Islam Siswa di SMA Negeri 2 Kelayang Kabupaten Indragiri Hulu." AlHikmah: Jurnal Agama dan Ilmu Pengetahuan 14.1 (2017): 76-95. https://doi.org/10.25299/alhikmah:jaip.2017.vol14(1).1528.

Harahap, Musaddad, dan Lina Mayasari Siregar. "Konsep Pendidikan Islam dalam Membentuk Manusia Paripurna." Jurnal Pendidikan Agama Islam Al-Thariqah 2.2 (2017): 98116. https://doi.org/10.25299/althariqa h.2017.vol2(2).1040.

Harapap, Musaddad. "Esensi Peserta Didik dalam Perspeektif Pendidikan Islam." Jurnal Pendidikan Agama Islam Al-Thariqah 1.2 (2016): 176185.

https://doi.org/10.25299/althariqa h.2016.vol1(2).625.

Hemiati. Model Pembelajaran. Aswajapress Sindo, 2012.

Hidaya, Noer, dan Lulu'atul Mudrikah. "Building Awarenes of Islamic Education: A Case Study in Wiyurejo Village, Pujon District,

Malang Regency." Didaktika Religia: Journal of Islamic Education 8.2 (2020): 222-226, doi:10.30762/didaktika.v8i2.2700.

Ibrahim. Metodologi Penelitian Kualitatif ,. Alfabeta, 2018.

Irman RN, Bustanul. "Upaya Guru Pendidikan Agama Islam Untuk Meningkatkan Kualitas Pembelajaran pada SMP Negeri di Kecamatan Soreang Kota Parepare." Jurnal Istiqra', vol. 7, no. 1, 2019.

Jaenuri. "Pengembanngan Soft Skill Guru." Jurnal Pendidikan Islam, vol. 05, no. 01 , 2017, doi:10.21274/taalum.2017.5.1.123140.

Maryance. "Penerapan Metode Pembelajaran Inkuiri pada Mata Pelajaran PAI dalam Meningkatkan Aktivitas Belajar Siwaa di SMA Negeri 10 Palembang." Jurnal Pendidikan Islam, vol. 6, no. 2, 2018, hlm. 342-43, doi:https://doi.org/10.29313/tjpi.v6 i2.4628.

Muhali. "Arah Pengembangan Pendidikan Masa Kini Menurut Perspektif Revolusi Industri 4.0." Jurnal Seminar Nasional, vol. 1, no. 1, 2018.

Mujiburrohman. "Implementasi Model Pembelajaran Inquiry Untuk Meningkatkan Prestasi Belajar Penjasorkes Pada Permainan Bola 
Basket Siswa XII MIA 2 di MAN Subang Tahun Pelajaran 2015/2016." Jurnal Pendidikan Guru FKIP, vol. 1, no. 2, 2018.

Musrifah. "Analisis Kritis Pendidikan Islam Indonesia di Era Global." Journal of Islamic Studies and Humanities, vol. 3, no. 1, 2018, hlm. 70-71, doi:https://doi.org/10.21580/jish.3 1.2341 .

Ni'amah, Khoirotul. "Paradigma Pendidikan Islam Perspektif AlGhazali." Jurnal Heutagogia, vol. 1, no. 1, 2021.

Ningsih, Tutuk. "Peran Pendidikan Islam dalam Membentuk Karakter Siswa di Era Revolusi Industri 4.0 pada Madsrasah Tsanawiyah Negeri 1 Banyumas." Jurnal Insania, vol. 24, no. 2, 2019, doi:https://doi.org/10.24090/insani a.v24i2.3049.

Noer, Ali, Syahraini Tambak, and Harun Rahman. "Upaya Ekstrakurikuler Kerohanian Islam (ROHIS) dalam Meningkatkan Sikap Keberagamaan Siswa di SMK Ibnu Taimiyah Pekanbaru." Jurnal Pendidikan Agama Islam Al-Thariqah 2.1 (2017): 21-38.

https://doi.org/10.25299/althariqa h.2017.vol2(1).645.

Nurdyansyah. Inovasi Model Pembelajaran. Nizama Learning Center, 2016.

Nurfadilah. "Teori dan Konsep Peserta Didik Menurut Al-Qur'an." Jurnal EduProf, vol. 1, no. 01, 2019, doi:https://doi.org/10.47453/edupr of.v1i2.16.

Nurmayani, Lia, dkk. "Pengaruh Model Pembelajaran Inkuiri Kemampuan Berpikir Peserta Didik." Jurnal Pendidikan Fisika dan Teknologi, vol. 4, no. 1, 2018, doi:http://dx.doi.org/10.29303/jpft. v4i.548.

Nursoh, Siti, dan Eva Luthfi Fakhru Ahsani. "Analisis Kesulitan Belajar Pendidikan Agama Islam (PAI) dan
Cara Mengatasinya." Jurnal Pendidikan Islam, vol. 05, no. 01, 2020, doi:http://dx.doi.org/10.29240/bela jea.v5i1.1145.

Prihartini, Eka, dkk. "Meningkatkan Kemampuan Berpikir Kritis Matematis Menggunakan Pendekatan Open Ended." Jurnal Matematika, vol. 1, no. 2, 2015.

Priyanto, Adun. "Pendidikan Islam dalam Era Revolusi Industri 4.0." Jurnal Pendidikan Islam, vol. 6, no. 2, 2020.

Ramayulis. Filsafat Pendidikan Islam. Kalam Mulia, 2015.

Ramayulis. Metodologi Pendidikan Agama Islam. Kalam Mulia, 1990.

Saharullah, dkk. "The Implementation of Inquiry: Based Learning to Imptove the Learning Result of Fotball." Journal of Education Science and Technology, vol. 5, no. 1, 2019, doi:https://doi.org/10.26858/est.v5 i3.11008.

Saputra, Anri. "Pendidikan Teknologi dan Tantangan dan Kesempatan." Jurnal Kajian Teori dan Hasil Penelitian Pendidikan 3.1 (2020): 56-69.

Sariah. "Impelementasi Pembelajaran Inkuiri pada Bidang Studi Aqidah Akhlak." Jurnal Kependidikan Islam 3.1 (2017): 155-166. http://dx.doi.org/10.24014/potensi a.v3i1.3489.

Solichin, Mohammad Muchlis. "Penerapan Model Pembelajaran Inkuiri dalam Pendidikan Agama Islam." Jurnal Tadris 12.2 (2017): 189-197.

Sukenti, Desi, and Syahraini Tambak. "Strengthening Islamic Psychosocial and Self-confidence in Develophing Student Thinking Creative." ICOSEEH 20194 (2019): 446-453. https://doi.org/10.5220/00093704 04460453.

Sukenti, Desi, Syahraini Tambak, and Charlina. "Developing Indonesian Language Learning Assessments: Strengthening the Personal 
Competence and Islamic Psychosocial of Teachers." International Journal of Evaluation and Research in Education 9.4 (2020): 1079-1087. https://doi.org/10.11591/ijere.v9i.2 0677.

Sukenti, Desi, Syahraini Tambak, and Ermalinda Siregar. "Learning Assessment for Madrasah Teacher: Strengthening Islamic Psychosocial and Emotional Intelligence." $\mathrm{Al}$ Ishlah: Jurnal Pendidikan 13.1 (2021): 725-740. https://doi.org/10.35445/alishlah.v $13 \mathrm{i} 1.552$

Suryabrata, Suryabrata. Metode penelitian. Rajawali Press, 1987.

Sutopo, Wahyu, dan Hoedi Prasetyo. "Industri 4.0: Telaah Klasifikasi Aspek dan Arah Perkembangan Riset." Jurnal Teknik Industri 13.1 (2018): $17-28$. https://doi.org/10.14710/jati.13.1.1 7-26.

Syamsuar, dan Reflianto. "Pendidikan dan Tantangan Pembelajaran Berbasis Teknologi Informasi di Era Revolusi Industri 4.0." Jurnal Ilmiah Teknologi 6.2 (2018): 176-189. https://doi.org/10.24036/et.v2i2.10 1343.

Syarif, Miftah. "Hakekat Manusia dan Implikasinya dalam Pendidikan Islam." Jurnal Pendidikan Agama IslamAl-Thariqah 2.2 (2017): 144155.

:https://doi.org/10.25299/althariqa h.2017.vol2(2).1042.

Tambak, Syahraini, and Desi Sukenti. "Strengthening Islamic behavior and Islamic psychosocial in developing professional madrasah teachers." Cakrawala Pendidikan: Jurnal Ilmiah Pendidikan 39.1 (2020): 65-78.

Tambak, Syahraini. "Pendidikan Etika Bergaul Islami Dalam Keluarga "Nilai Pendidikan Etika Berlaku Adil Orangtua dengan Anak dalam
Pergaulan Keluarga Perspektif Hadits"." Jurnal Pendidikan Agama Islam Al-Thariqah 4.1 (2019): 1-20. https://doi.org/10.25299/althariqah.2019.vol4(1).2910.

Tambak, Syahraini, et al. "Profesionalisme Guru Madrasah: Internalisasi Nilai Islam dalam Mengembangkan Akhlak Aktual Siswa." Jurnal Pendidikan Agama Islam Al-Thariqah 5.2 (2020): 79-96. https://doi.org/10.25299/althariqah.2020.vol5(2).5885.

Tambak, Syahraini, Amril M, Zuriatul Khairi, and Desi Sukenti. "Development of Madrasah Teacher Professionalism by Strengthening the Khalifah Concept and Islamic Psychosocial Perspective." International Conference on Islamic Education (ICIE 2018). Atlantis Press, 2018. https://doi.org/10.2991/icie18.2018.7.

Tambak, Syahraini. "Filsafat Idealisme dan Implikasinya pada Teori Pendidikan." Al-Hikmah 11.1 (2014): 61-75.

Tambak, Syahraini, M. Yusuf Ahmad, and Desi Sukenti. "Strengthening Emotional Intelligence in Developing the Madrasah Teachers' Professionalism (Penguatan Kecerdasan Emosional dalam Mengembangkan Profesionalisme Guru Madrasah)." Akademika 90.2 (2020). https://doi.org/10.17576/akad2020-9002-03.

Tambak, Syahraini, et al. "Internalization of Riau Malay Culture in Developing the Morals of Madrasah Ibtidaiyah Students." Al Ibtida: Jurnal Pendidikan Guru MI 7.1 (2020): 6984.

https://doi.org/10.24235/al.ibtida.s nj.v7i1.5954.

Tambak, Syahraini, and Desi Sukenti. "Pengembangan profesionalisme guru madrasah dengan penguatan 
konsep khalifah." Hayula: Indonesian Journal of Multidisciplinary Islamic Studies 4.1 (2020): 41-66. https://doi.org/10.21009/004.01.0.

Tambak, Syahraini. "Pendidikan Agama Islam; Konsep Metode Pembelajaran PAI." (2014).

Tayeb, Tamhrin. "Analysis and Benefits of Learning Models." Jurnal Auladuna 4.2 (2017): 145-159. https://doi.org/10.24252/auladuna. v4i2a5.2017.

Usman, A. Samad, dan Abdul Hadi. "Hakikat Peserta Didik dalam Pendidikan Islam (Suatu Kajian Teorik)." Jurnal Mimbar Akademika 5.2 (2020): 165-174.
Yuliharti. "Soft Skills Guru Pendidikan Agama Islam di Tingkat Sekolah Menengah Pertama Kota Pekanbaru." Jurnal Murabby 2.1 (2019): 67-81. doi:10.15548/mrb.v2i1.326.

Zulmy, Biqih. "Pendidik dalam Perspektif Al-Qur'an." Jurnal Ilmiah Mahasiswa Raushan Fikr 9.2 (2020): 81-82.

Zulvawati, Aini, dkk. "Penerapan Model Pembelajaran Inkuiri dalam Meningkatkan Kreativitas Belajar Siswa pada Mata Pelajaran Al-Islam di SMP Muhammadiyah 4 Palembang." Jurnal PAI Raden Patah 1.1 (2019): 65-66. doi:https://doi.org/10.19109/pairf.v $1 \mathrm{i} 1.3011$. 